\title{
The Influence of Corporate Social Responsibility on Financial Performance: The Case of IKEA
}

\author{
Alaa Baraka ${ }^{1}$, Hiba Al Farkh ${ }^{2}$ \\ ${ }^{1}$ Faculty of Economics, Damascus University \\ ${ }^{2}$ Faculty of Business Administration, Arab International University \\ I'dr.barakaal@gmail.com; ${ }^{2 h}$-alfarkh@aiu.edu.sy
}

\begin{abstract}
This study analyzed the impacts of corporate social responsibility (CSR) represented by four different dimensions: eco, gender, turbines, and program-tack on financial performance measured by net income. For achieving this aim, we apply cointegration methodology using the ARDL method. Data was collected from the financial statements of IKEA published online on the official IKEA website from 2009 to 2019 . The results indicate that there is a significant positive impact of both turbines and program-tack on net income, while there is a negative impact of gender on net income.
\end{abstract}

Keywords: Corporate social responsibility, ardl, program-tack, net income, ikea 


\section{Introduction}

Corporate social responsibility (CSR) is a management approach where firms merge social and ecological concerns in their business processes and interconnection with their stakeholders. CSR is mainly known as achieving a balance of economic, environmental, and social imperatives, parallel dealing with the expectations of shareholders and stakeholders. It is essential to distinguish between CSR and charity, sponsorships or philanthropy in this context. Despite that, the last can also present a valuable contribution to poverty reduction, will directly better the reputation of a company and strengthen its brand locally and globally, which may reflect as a new competitive advantage in the market based on a meaningful internal and external image of a company (Shulili Du et al., 2010).

CSR is no longer considered luxury practices companies adopted to improve their images intrinsically and extrinsically; it is pivotal to ensure the continuation and sustainability of the organization. Furthermore, the implementation of CSR takes different aspects like; environmental management, eco-efficiency, responsible sourcing, stakeholder engagement, labor standards and working conditions, employee and community relations, social equity, gender balance, human rights, good governance, and anti-corruption measures.

After this concise introduction about CSR, let's shed light on the importance of this study, which about the significance effects of CSR on the company's financial performance. On the other side, this study focuses on four main factors for CSR: (a) ECO dimension, (b) Program-Tack, (c) Turbines, (d) Gender. On the same rhythm, the financial performance had been measured through net income in the light of the data we collected, where the data had been extracted from the official websites of IKEA.

The previous lines coined the following question: How do CSR practices affect financial performance? We will have a depth perception of the CSR impact on financial performance by answering this question.

\section{Literature Review}

Orlitzky \& Benjamin (2001) research included expanding on prior work on the connection between corporate social execution (CSP) and a company's money related execution. This integrative observational investigation bolsters the hypothetical contention that the higher an association's CSP, the lower its budgetary hazard. In particular, the connection between CSP and hazard seems, by all accounts, to be one of complementary causality because earlier CSP is adversely identified with resulting monetary risk, and the earlier budgetary threat is contrarily identified with ensuing CSP. Furthermore, CSP is all the more unequivocally related with proportions of a market chance than proportions of bookkeeping hazard. Of all CSP measures, notoriety for social duty seems, by all accounts, to be the most significant one as far as its hazard suggestions. We conclude the negative 
correlation between the independent variable corporate social responsibility and the dependent variable corporate financial performance that showed the impact of CSR on reducing the risk for the market on a large scale and for the monetary hazard that reflects an effect that leads to better financial performance for the organization.

Another research was achieved by Pivato et al. (2007), who studied the fundamental and famously tricky issue in CSR and the effect of CSP on the primary concern. Rather than searching for direct connections among social and monetary exhibitions, it estimated that the principal consequence of CSR exercises is the production of trust among the partners. A review directed on purchasers of natural items offered help for our speculation, indicating that CSP impacts buyer trust and that that trust thus impacts shoppers' ensuing activities. The discoveries further recommend that halfway factors among CSP and CFP may best help a business case for CSR. We conclude that corporate social responsibility as an independent variable impacts financial performance as a dependent variable. However, a mediator variable, which is building trust with stakeholders, especially customers, reflects the stakeholders' dimension of corporate social responsibility on profitability.

Next year, Beurden \& Gössling (2008) introduced literature that was one of the more seasoned inquiries in the discussion about CSR: whether it is beneficial for associations to focus on cultural requests. This discussion was inwardly, normatively, and ideologically stacked. Up to the present, this inquiry has been a significant trigger for observational exploration in CSR. Nonetheless, the response of the investigation has not been found at this point. In any event, that is the thing that numerous analysts state. This evident indecision in CSR results welcomes a writing study that can explain the discussion and consider the making of determinations. The aftereffects of the writing study performed here uncover that there is to be sure clear exact proof for a positive relationship between corporate social and money-related execution. Voices that express the inverse allude to outdated material. Since the beginnings of the CSR banter, social orders have changed. We can in this way express that, for the current Western culture, "Great Ethics is Good Business." And in conclusion, this literature shows the impact of corporate social responsibility with all dimensions on the financial impact on organizations through building a good reputation and therefore a strong brand name in the society that make more successful and profitable.

In the same year, Huang Lin et al. (2008) make research includes a few examinations' contemplates have inspected corporate social duty (CSR) and its impacts on business execution; however, their outcomes change broadly. This may originate from defective examinations by relapsing money-related execution on corporate social performance and maybe from a few insufficiently controlled factors. Past examinations didn't perceive interest in innovative work as a fundamental variable because there is impressive exact proof that it has a solid positive effect on 
gainfulness. This misidentification makes one-sided evaluations of the monetary effect of CSR. Somewhere in the range of 2002 and 2004, we inspected 1000 Taiwanese cases as a sample in which firms incorporate their $R \& D$ as a business technique they use for the maintainable turn of events; they also consider their magnanimous uses as commitments to CSR. In light of hypothetical declarations and observational proof in writing, we distinguished a positive connection between CSR and money-related execution. When the model is appropriately indicated, we found that while CSR doesn't have a lot of positive effect on momentary monetary execution, it offers a striking long-haul financial bit of leeway. Consequently, the literature shows the real effect of CSR on financial performance, especially with the dimension of social responsibility, including charitable expenditures as CSR contributions.

McGuire et al. (2017) investigated the connections between the impression of firms' corporate social obligation and proportions of their money-related execution. Results show that an association's earlier exhibition, surveyed by financial exchange returns and bookkeeping-based measures, is more firmly identified with corporate social duty than with ensuing execution. Results additionally show that proportions of hazard are more firmly connected with social obligation than past investigations have proposed. Therefore, the impact of corporate social responsibility on corporate financial performance shows that risk measures are more closely associated with it.

Also, Singh et al. (2017) studied the effect of CSR dimensions on firm value. They evaluated the impact of six CSR dimensions on the firms' stock market value over three years period. They found a significant impact of CSR practices and initiatives related to community investment through philanthropy and enhancing workplace quality on firm value. Another research introduced by Amiri (2019) found that officials have different perceptions about the CSR concept and adopted different CSR approaches. However, it did not study the impact of CSR on firm performance. In the same context, Wu et al. (2020) revealed that CSR has an impressive positive impact on the financial performance of Chinese listed companies in the manufacturing industry, and the relation is more significant for stable firms.

\section{IKEA Corporate Social Responsibility and Development of Financial Performance}

IKEA embarked on many activities to support the different derivatives for CSR, such as; educating and empowering employees and setting the issues of gender equality and minorities within the company. Moreover, as one of the global companies, IKEA put up an idea to eliminate its energy consumption and generate energy from alternative sources. Recently, IKEA has addressed sustainable sourcing as an additional CSR issue that IKEA considers within the range of its operations.

IKEA supported local communities through supporting events in Sweden 
organized by charities that provide backs filled with toys and gifts to kids. Also, IKEA has planted around one million trees in the UK. In addition, IKEA workers in Australia have enhanced environments where children live and grow.

IKEA enriched its contribution in educating and empowering employees through introducing an unusual hourly wage structure that concentrates on workers' needs. IKEA has enabled its staff access to face-to-face and digital learning solutions. Also, IKEA ensured that $55 \%$ of all workers and $40 \%$ of all managers are women. The following chart illustrates women's progress in IKEA co-workers between 20092019.

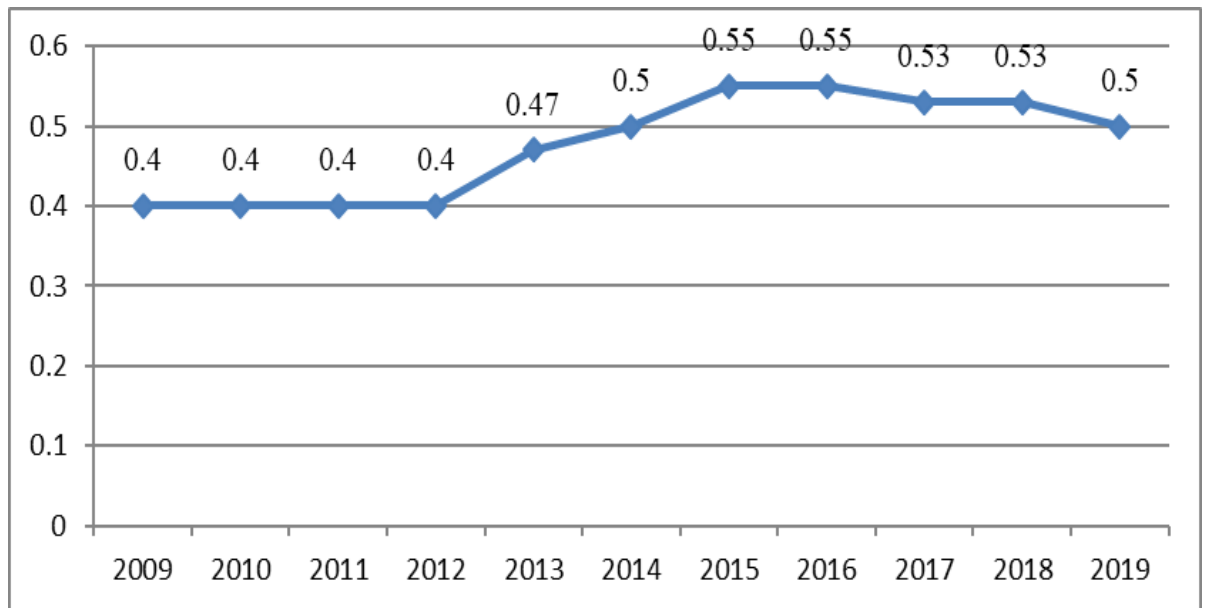

Fig. 1: Development of women share in IKEA co-workers (Source: prepared by researchers depending on a research data set)

From an environmental perspective, IKEA recorded a lot of achievements, such as the ownership and operating 327 wind turbines worldwide, investing 730,000 solar panels on its buildings worldwide. IKEA also has around $60 \%$ of all goods manufactured by the furniture retailer based on renewable materials, and $10 \%$ of goods contain recycled materials. IKEA aims to use $100 \%$ renewable and recycled materials by 2030. It organized an initiative that saved 1,400 tons of food, equivalent to three million meals. The figures (2) and (3) illustrated the development achieved by IKEA concerning the environmental dimension represented by the number of trees planted annually and the number of wind turbines it established each year during the study period. 


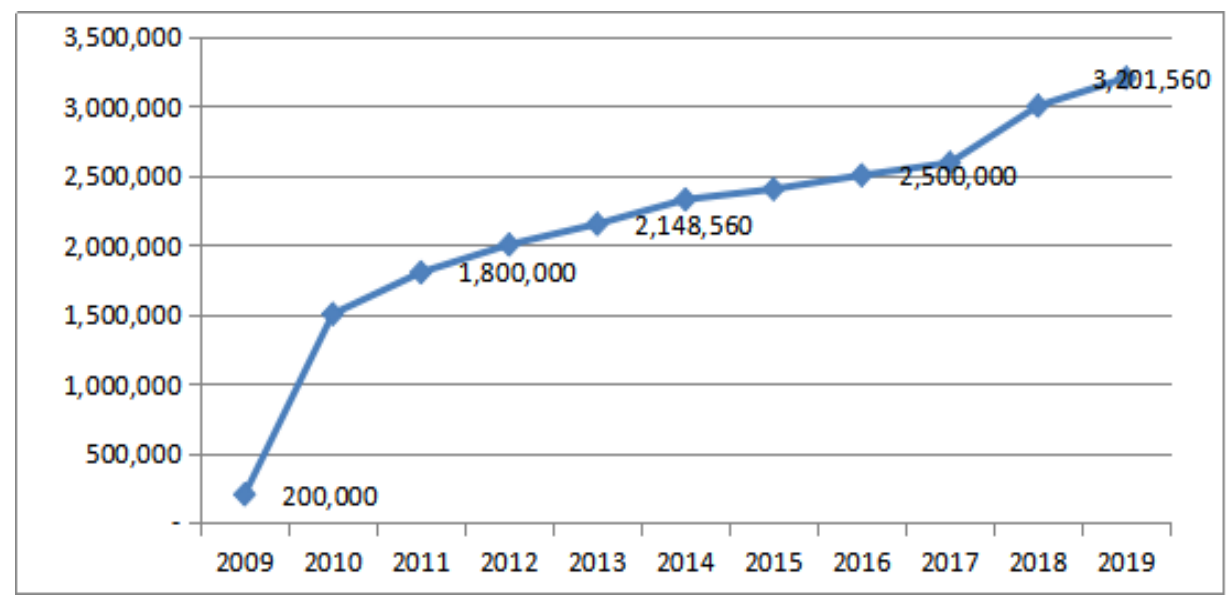

Fig. 2: Development of eco-dimension for IKEA (Source: prepared by researchers depending on research data set)

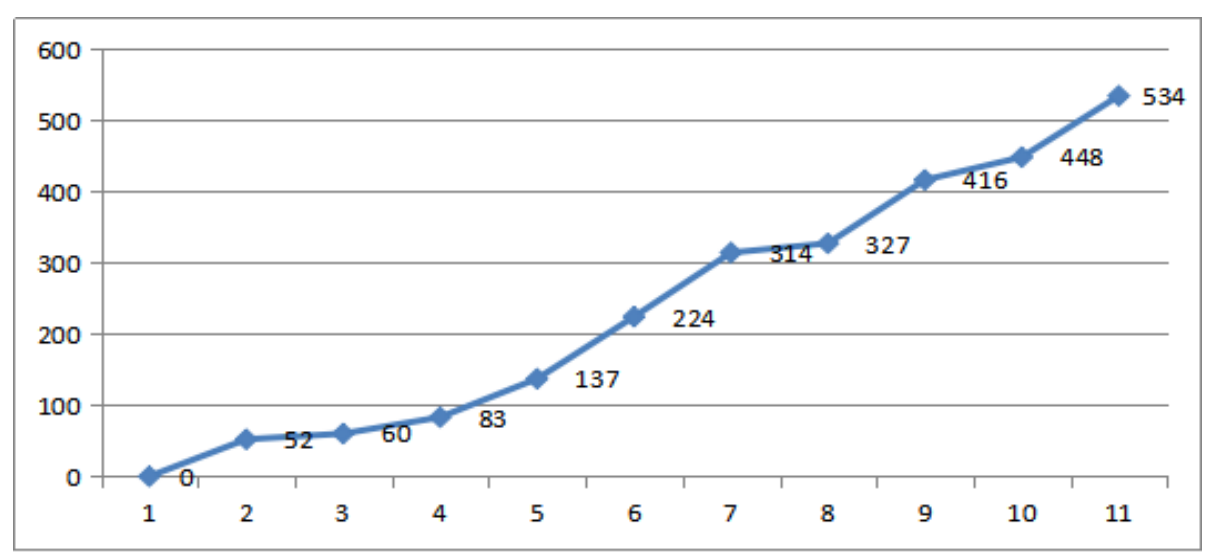

Fig. 3: Development of wind turbines (Source: prepared by researchers depending on research data set)

IKEA other CSR initiatives and charitable donations are: the IKEA foundation donated more than 7.7 million EUR to enhance the standard of living for Refugees campaign; IKEA implements Supplier Code of Conduct that refuses the use of child labor, in addition to forced or bonded labor and discrimination at work; IKEA Foundation has donated a euro to save the children for each soft toy sold in IKEA markets in November and December since 2003. 


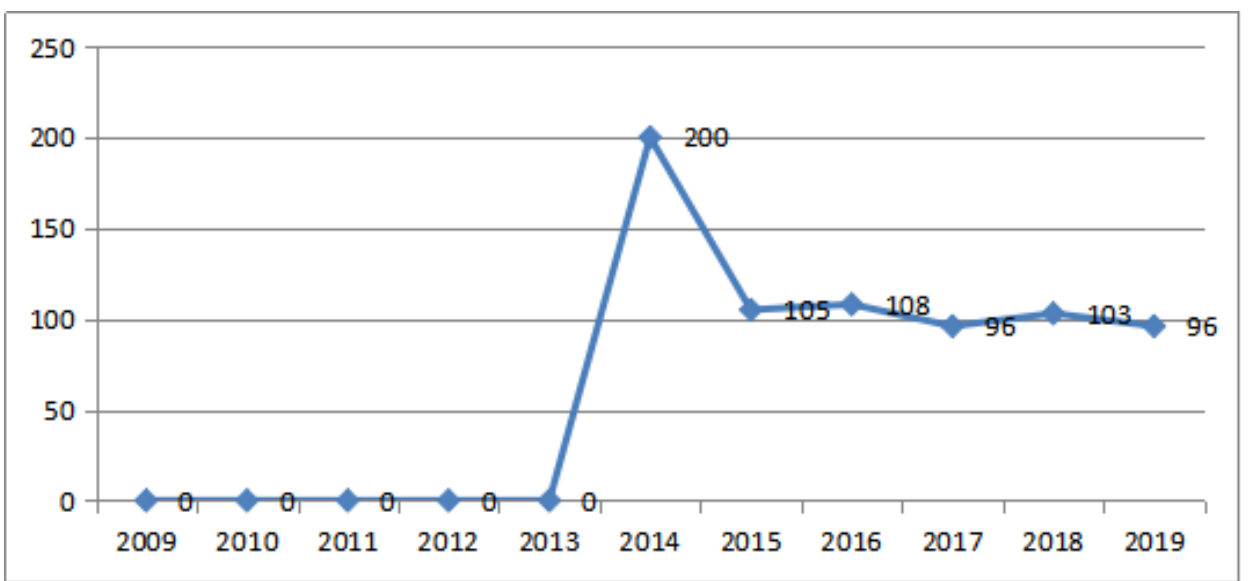

Fig. 4: Development of IKEA program - TACK (Source: prepared by researchers depending on research data set)

Financial performance is a profound subject with a broad scope of measurements and indications. Primarily, it elaborates on how well a firm can use different assets from its primary business and generate revenues. On the other side, this term is utilized as a general measure of the firm's overall financial health at a specific period.

There are many indicators in measuring financial performance. In contrast, in this research, in the light of the available data for IKEA -which was available on the official website IKEA financial statements- the net income is the approved measure for financial performance. Fig. 5 reflects the changes in the net income achieved by IKEA during the analyzed time.

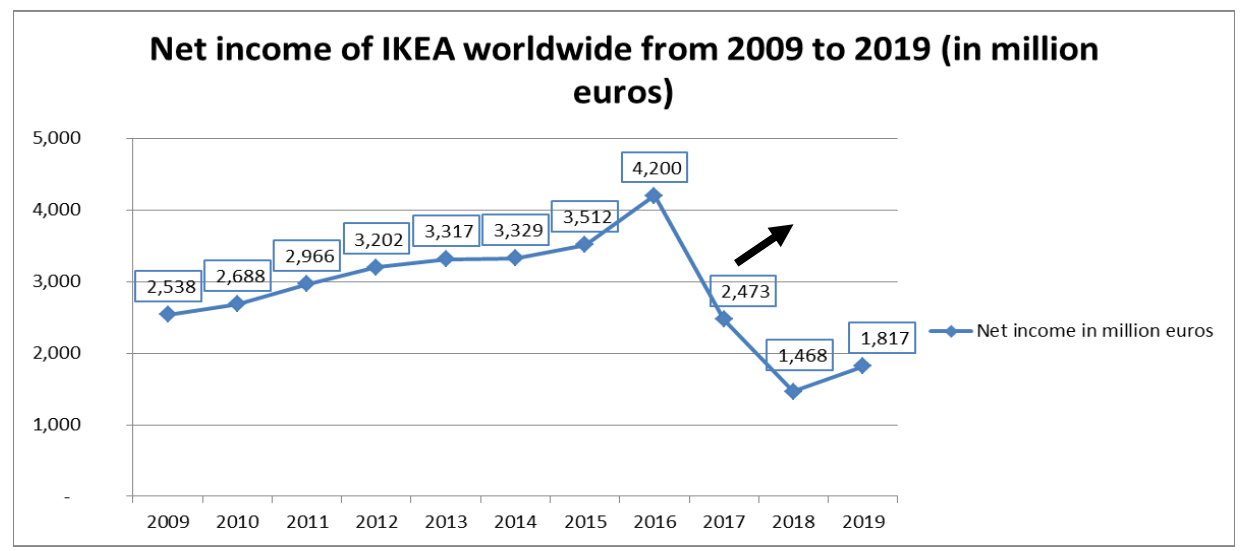

Fig. 5: Development of IKEA net income (Source: prepared by researchers depending on research data set) 


\section{The Model Specification and Data Description}

The model of this research takes the following functional form:

$$
N I=\beta 0+\beta 1 \text { Eco }+\beta 2 \text { Gen }+\beta 3 \text { ProTack }+\beta 4 \text { Turbine }+\varepsilon
$$

Where $\beta_{0}$ : intercept term, the $\varepsilon_{t}:$ random error term

This equation is used to test the following four hypotheses:

H1: Eco dimension affects the net income.

$\mathrm{H} 2$ : The percentage of women co-workers affects the net income.

H3: The Program-Tack has a positive effect on net income.

H4: The Turbine has a positive effect on Net Income for the long term.

According to the previous model, the study's variables are split into two main types: independent and dependent. Independent variables represented by CSR practices are four different indicators: eco indicator, wind turbines, program-tack, gender. The dependent variable is financial performance, measured by net income.

This research uses an annual data series for eleven years, from 2009 to 2019. All variables' time series are extracted from IKEA's official website. Table 1 shows a detailed explanation, sources, and codes of all variables.

Table 1: Data description (prepared by researchers)

\begin{tabular}{|c|c|c|}
\hline Data & Code & Measure \\
\hline $\begin{array}{c}\text { NET_INCOME (million } \\
\text { Euros) }\end{array}$ & NI & $\begin{array}{c}\text { Annual balance of the Net Income from the } \\
\text { financial statement }\end{array}$ \\
\hline $\begin{array}{c}\text { Eco - dimension } \\
\text { (reforestation program) } \\
\text { across the USA only }\end{array}$ & Eco & $\begin{array}{c}\text { The number of planted trees based on the } \\
\text { reforestation program }\end{array}$ \\
\hline Gender & GEN & (\% of women from all IKEA co-workers $)$ \\
\hline $\begin{array}{c}\text { Program-Tack } \\
\text { (million Euros) }\end{array}$ & $\begin{array}{c}\text { PRO- } \\
\text { TACK }\end{array}$ & $\begin{array}{c}\text { Annual balance for the pro-tack from the } \\
\text { financial statement }\end{array}$ \\
\hline Wind Turbines & TURBIN & Number of wind turbines \\
\hline
\end{tabular}

\section{Empirical Results and Discussion}

In this section, the research shows the descriptive statistics of variables undertaken, the nature of these variables' series, whether they were stationary or not, the result of bounds tests, the ARDL estimated model, and finally, the results of diagnostic tests. First, the above variables' descriptive statistics show some values of central tendency, dispersion, and distribution measures (Table 2). 
Table 2: Descriptive statistics of the study variables (Source: researcher using data published in the official IKEA website)

\begin{tabular}{|c|c|c|c|c|c|}
\hline & NI & ECO & GEN & PRO-TACK & TURBIN \\
\hline Mean & 2,865 & $2,151,285$ & 0.47 & 64 & 236 \\
\hline Median & 2,966 & $2,325,011$ & 0.49 & 96 & 224 \\
\hline Maximum & $\begin{array}{c}4,200 \\
\text { (year 2016) }\end{array}$ & $\begin{array}{c}3,201,560 \\
(\text { Year 2019) }\end{array}$ & $\begin{array}{c}0.55 \\
\text { year(2016) }\end{array}$ & $\begin{array}{c}200 \\
\text { (year 2014) }\end{array}$ & $\begin{array}{c}534 \\
\text { (year 2019) }\end{array}$ \\
\hline Minimum & $\begin{array}{c}1,468 \\
(\text { year 2018) }\end{array}$ & $\begin{array}{c}200,000 \\
(\text { Year 2009) }\end{array}$ & $\begin{array}{c}0.4 \\
\text { (Year 2009) }\end{array}$ & $\begin{array}{c}0 \\
\text { before 2014 }\end{array}$ & $\begin{array}{c}0 \\
\text { (year 2009) }\end{array}$ \\
\hline Std. Dev. & 780 & 812,811 & 0.06 & 68 & 183 \\
\hline Jarque-Bera & 0.738046 & 2.992656 & 1.179095 & 0.682580 & 0.919891 \\
\hline Probability & 0.691409 & 0.223951 & 0.554578 & 0.710853 & 0.631318 \\
\hline
\end{tabular}

From the results are given in Table 2, we conclude the following issues:

The Mean of net income was 2,865 billion euros, while the maximum value was in 2016, which registered 4,200 billion euros, compared with the last year 2015 Ikea net income soars $20 \%$ in 2016, this highest value maybe causes of many reasons:

1) The complicated corporate structure of IKEA allows for its parent company-a nonprofit foundation (The Stitching INGKA Foundation is one of the largest charitable foundations in the world and is registered in the Netherlands) - to minimize its taxes.

2) In 2014, IKEA started Program-Tack for showing appreciation for its workers; this may enhance the reputation and the external image of IKEA and its commitment to support its employees worldwide. These points have been reflected by increasing the revenue.

3 ) The percentage of women in IKEA registered the highest value in $2016(55 \%)$. If we compare this value with the net income, we may assume that women may play a pivotal role in the financial productivity of IKEA. The following model will either support this assumption or not.

4) China was one of the company's fastest-growing markets. In 2016 also based on sales, China was one of the top five between Germany, the US, France, and the UK.

The Minimum net income was registered in 2018, which reached 1,468 billion euros this fall in net income by $41 \%$ compared with 2017 because of the increase of IKEA spending on renewable energy and made new investments in its online operation; from the other side spending on Program-Tack increased $7 \%$ comparing with 2017.

Eco dimension follows a normal increase, where the company encourages people to be aware of nature and the role of trees to eliminate $\mathrm{CO} 2$ pollution. The minimum value was in 2009 where the company was still at the beginning of its 
reforestation program. The same explanation for Program-TACK, which IKEA started in 2014, Wind Turbines began in 2010 by only 52 Turbines, and 2019 Ikea had 534 turbines.

In the light of the Jarque-Bera test, the p-value of J-B for all variables was greater than 0.05 , so we accept the null hypothesis that the data of the study variables follow a normal distribution.

By moving to analyze the time series of study' variables, the first step will be studying the stationarity with the unit root test represented by (Phillips- Perron test, PP). The results of the PP test are presented in Table 3.

According to the results presented in Table 3, we accept the null hypotheses ( $\mathrm{H} 0$ : variable has unit root) in level and reject it in first difference for the variables: Net Income, GEND, TURBIN, and Pro-tack at different levels of the confidence interval, which means that all series were not stationary in level, while they were in first difference. In contrast, the results showed the stationary of ECO in level at 99\% confidence interval, which means the degree of integration for ECO is zero.

In the light of the unit root test PP's results for stationarity, the best methodology for studying the relationship between financial performance and corporate social responsibility is the cointegration approach. Because the studied variables series were integrated into different degrees $(0,1)$, the study applied Autoregressive Distributed Lag (ARDL) models based on the Bounds testing approach.

Table 3: PP Unit Root Test Results (edited by researcher depending on the outcomes of Eviews 10)

\begin{tabular}{|c|c|c|c|c|c|c|c|}
\hline \multirow{2}{*}{$\begin{array}{c}\text { Varia } \\
\text { ble }\end{array}$} & \multicolumn{3}{|c|}{ LEVEL } & \multicolumn{3}{|c|}{ 1ST DIFFERENCE } & \multirow{2}{*}{$\begin{array}{c}\text { integrated } \\
\text { degree }\end{array}$} \\
\hline & $\mathbf{N a}$ & $\mathbf{C} \mathbf{b}$ & $\mathrm{C}+\mathrm{T} \mathrm{d}$ & $\mathbf{N}$ & C & $\mathbf{C}+\mathbf{T}$ & \\
\hline $\begin{array}{c}\mathrm{NET}_{-} \\
\mathrm{INCO} \\
\mathrm{ME}\end{array}$ & $\begin{array}{c}- \\
0.702\end{array}$ & -1.65 & -1.963 & $-4.042 * *$ & $-3.963 *$ & $-7.657 * * *$ & $\mathrm{I}(1)$ \\
\hline ECO & $\begin{array}{c}- \\
1.221\end{array}$ & $\begin{array}{c}- \\
3.65^{*}\end{array}$ & $-9.21 * * *$ & & & & $\mathrm{I}(0)$ \\
\hline $\begin{array}{c}\text { GEN } \\
\mathrm{D} \\
\end{array}$ & 3.473 & -0.35 & -2.707 & $-2.382 * *$ & $-3.739 * *$ & -3.202 & $\mathrm{I}(1)$ \\
\hline $\begin{array}{l}\text { PROT } \\
\text { ACK }\end{array}$ & $\begin{array}{c}- \\
0.992\end{array}$ & -1.89 & -2.471 & $-4.469 * * *$ & $-5.93 * * *$ & $-7.158 * * *$ & $\mathrm{I}(1)$ \\
\hline $\begin{array}{l}\text { TUR } \\
\text { BIN }\end{array}$ & 3.564 & 1.167 & -1.826 & -0.719 & $-3.018^{*}$ & $-3.478^{*}$ & $\mathrm{I}(1)$ \\
\hline
\end{tabular}

Note: $* * *, * *, *$ mean stationary at the $1 \%, 5 \%$ and $10 \%$ respectively. a, b, d indicates the type of test equation without intercept, with intercept and with intercept and trend, respectively

Moving to estimate the impact of the independent variable CSR represented through four different indicators (ECO, GEND, PRO-TACK, and TURBINE) on financial performance, and after testing various econometrics models, the best- 
estimated model is ARDL $(1,1,1,1)$ which studied the effect of (GEND, PROTACK, and TURBINE) on IKEA financial Performance (Net Income) and excluded ECO because of nonintegrated of the estimated function when it inserted. Table 4 clarifies the result of the Bound-Test on the study' model.

Table 4: The Result of Bound Test

\begin{tabular}{|c|c|c|c|c|}
\hline Test Statistic & Value & Signif. & $\mathbf{I}(\mathbf{0})$ & $\mathbf{I}(\mathbf{1})$ \\
\hline F-statistic & 4.612067 & $10 \%$ & 2.37 & 3.2 \\
\hline K & 3 & $5 \%$ & 2.79 & 3.67 \\
\hline & & $2.5 \%$ & 3.15 & 4.08 \\
\hline & & $1 \%$ & 3.65 & 4.66 \\
\hline
\end{tabular}

The calculated F-statistic of the Bounds test (Table 4), is greater than the upper bound of I(1). Thus, it rejects the null hypothesis (H0: no cointegration relationship among the variable) and emphasizes the presentence of the long-run relationship between net income and other variables.

Depending on the output (Table 5), we may write the following model for the impacts of CSR indicators on financial performance represented by net income as follows:

$$
N I=28752.17+36.42 \text { ProTack }+8.28 \text { Turbine }-66066.06 \mathrm{Gena}
$$

Table 5: Long Run Estimate of Net Income and CSR Indicators

\begin{tabular}{|c|c|c|c|c|}
\hline Variable & Coefficient & Std. Error & t-Statistic & Prob. \\
\hline PROTACK & 36.42252 & 1.297627 & 28.06856 & 0.0013 \\
\hline TURBIN & 8.288898 & 0.986673 & 8.400857 & 0.0139 \\
\hline GEND & -66066.06 & 4053.022 & -16.30045 & 0.0037 \\
\hline C & 28752.18 & 1547.239 & 18.58289 & 0.0029 \\
\hline
\end{tabular}

The previous results indicate that Pro-Tack and TURBIN have a positive and statistically significant impact on financial performance at 5 percent significance level. In comparison, the GEN has a negative and statistically significant impact on financial performance at 1 percent level of significance. Now, on the effect of CSR indicators on the indicator of financial performance in the short run, the following table shows the results of the Error Correction Model.

Table 6: Short Run Estimate for Financial Performance

\begin{tabular}{|c|c|c|c|c|}
\hline Variable & Coefficient & Std. Error & t-Statistic & Prob. \\
\hline D(PROTACK) & 161.4550 & 19.02122 & 8.488151 & 0.0136 \\
\hline D(TURBIN) & 36.49665 & 5.011804 & 7.282137 & 0.0183 \\
\hline
\end{tabular}




\begin{tabular}{|c|c|c|c|c|}
\hline D(GEND) & -7318.296 & 4509.466 & -1.622874 & 0.2461 \\
\hline ECT (-1) & -7.865862 & 0.945699 & -8.317512 & 0.0141 \\
\hline R-squared & 0.944520 & \multicolumn{2}{|c|}{ Mean dependent var } & -104.8000 \\
\hline Adjusted R-squared & 0.916780 & \multicolumn{2}{|c|}{ SD dependent var } & 1138.559 \\
\hline SE of regression & 328.4494 & \multicolumn{2}{|c|}{ Akaike info criterion } & 14.71582 \\
\hline Sum squared resid & 647273.9 & \multicolumn{2}{|c|}{ Schwarz criterion } & 14.83685 \\
\hline Log-likelihood & -69.57908 & \multicolumn{2}{|c|}{ Hannan-Quinn criter. } & 14.58304 \\
\hline Durbin-Watson stat & 2.586710 & & \\
\hline
\end{tabular}

We conclude that:

Both Turbine and Pro-Tack have a positive and statistically significant impact on financial performance at $95 \%$ confidence interval.

The GEND has a negative and not statistically significant impact on financial performance.

The coefficient of the Error Correction Term is negative and not statistically significant at $95 \%$ confidence interval. The speed of adjustment to reach the longrun equilibrium position is estimated at $786 \%$ annually.

The power of the explanation of the model reached $92 \%$ approximately based on Adjusted R-squared, which means the changes in the CSR indicators can explain $92 \%$ from the changes in the company's net income; this refers to the importance of the CSR indicators in the financial performance.

A set of diagnostic tests was applied by moving to evaluate the estimated model according to the econometrics standers, and their results were inserted in the following tables. The problem of heteroskedasticity isn't exited in our model, and the variance of model residual is homoscedasticity.

Table 7: The Result of Heteroskedasticity Test (Breusch-Pagan-Godfrey)

\begin{tabular}{|c|c|c|c|}
\hline F-statistic & $\mathbf{0 . 5 0 2 1 7 3}$ & Prob. F(7,2) & $\mathbf{0 . 7 9 3 3}$ \\
\hline Obs*R-squared & 6.373666 & Prob. Chi-Square(7) & 0.4969 \\
\hline Scaled explained SS & 0.389217 & Prob. Chi-Square(7) & 0.9998 \\
\hline
\end{tabular}

Also, the Ramsey Reset Test result was good, and the null hypothesis of this test shows the model is good fitness, and the problem of misspecification doesn't exist (Table 8).

Table 8: The Result of Ramsey Reset Test

\begin{tabular}{|c|c|c|c|}
\hline & Value & df & Probability \\
\hline t-statistic & 2.014196 & 1 & 0.2934 \\
\hline F-statistic & 4.056985 & $(1,1)$ & 0.2934 \\
\hline
\end{tabular}

This indicates that non-normality or autocorrelation of error terms problems are 
not issues of concern, as well as no evidence is found of autoregressive conditional heteroskedasticity. The variables are homoscedastic, and the functional form of the short-run model is well organized.

Figure 6 shows that the cumulative sum of recursive residuals and squares residuals of the estimated model has parameter constancy over the study period (2009- 2019) since plots of both CUSUM and CUSUM of squares statistics are always within the five percent critical bounds of parameter stability.

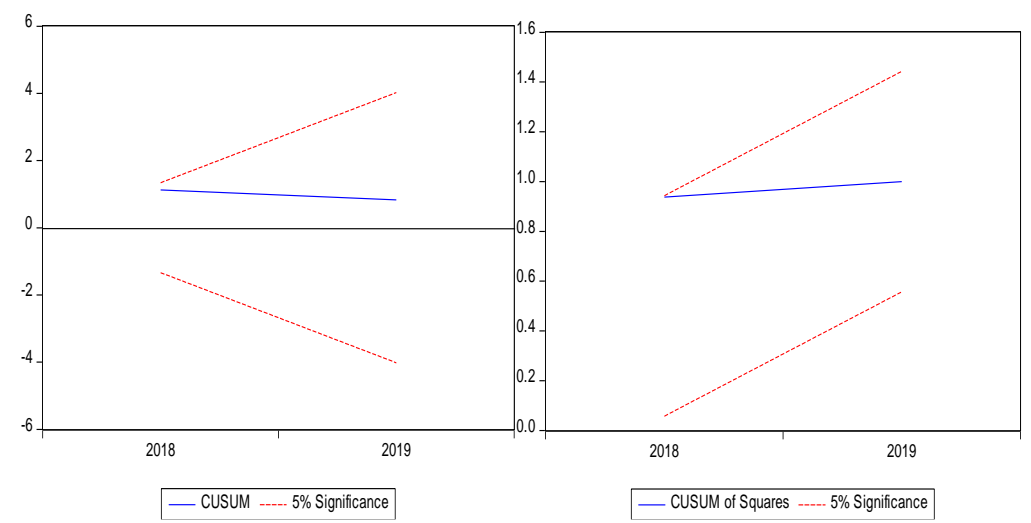

The straight lines represent critical bounds at a 5\% significance level

Fig. 6: Plots of Cumulative Sum of Recursive Residuals and Squares Residuals

In addition, the residuals undergo normal distribution because the probability of Jarque- Bera statistic was more significant than the level of significance (5\%) (Fig. 7).
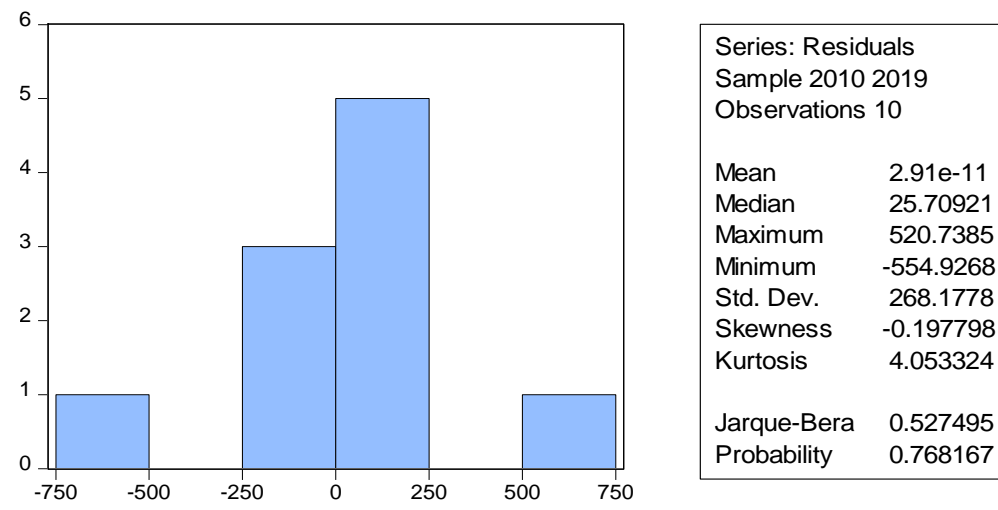

Fig. 7: The residuals distribution of estimated model

\section{Conclusions}

This study aims to clarify the impact of CSR on the Financial performance of one of 
the largest and universal companies in the world. To achieve this aim, the researchers apply the cointegration methodology (ARDL) method. The results clear that both TURBINE and PROTACK have a significant positive effect on net income in the long run. This indicates financial performance measured by net income relies heavily on employees at first place and renewable energy. This requires that organizations in all different sectors take reasonable steps towards CSR practices like alternative energy sources, the transition to the green economy, activate the empowerment initiatives, and uplift the employees to better levels, whether from the financial or skills side. But according to the results, financial motivations play a critical role in enhancing the job's whole internal environment.

Also, the results showed negative effects of gender on net income. However, the Company IKEA registered high levels of women sharing in all levels of management. This negative effect may lie in women's critical role in management positions more than in executive positions.

On the other side, the eco dimension does not play any significant role in financial performance. On the contrary, it ruined the whole model. We consider this because customers fund the entire reforestation program that IKEA supports; "donate $1 \$$ to plant one tree" this policy may help enhance the external image and reputation of IKEA and help support social awareness toward mother nature. Still, it does not have any direct impact on financial performance.

\section{References}

Amiri, M. (2019). A study of corporate social responsibility (CSR) initiatives of selected organizations in and around Pune city, state of Maharashtra, India. Religación. Revista De Ciencias Sociales Y Humanidades, 4(16), 375 - 383.

Beurden P. \& Gössling, T. (2008), The worth of values - a literature review on the relation between corporate social and financial performance, Journal of Business Ethics, 82(2), 407-424.

Griffin, J. \& Mahon, J. (1997). The corporate social performance and corporate financial performance debate: twenty-five years of incomparable research, Business\& Society, 36(5), 5-31.

How to lead the decade of action: Finance, Adaptation, Collaboration, Unilever, Patagonia, Ikea, Black Rock, and The Church of England Pension Board on Leading the Decade of Action; the responsible Business Summit Europe 2020, between 26-28 May, London <https://www.csrwire.com/press_releases/43681Unilever-Patagonia-Ikea-BlackRock-and-The-Church-of-England-Pension-Boardon-Leading-the-Decade-of-Action>. 
IKEA Report. (2018). Gender-pay-Gap report, published by IKEA Group <https://www.ikea.com/gb/en/files/pdf/58/85/5885f9bf/ikea-gender-pay-gap-report2018> [accessed 1/1/2021].

IKEA Report. (2019). Our responsibility, IKEA Group <https://www.ikea.com/ms/en_JP/about_ikea/our_responsibility> [accessed 5/12/2019].

IKEA Report. (2019). Work with us -the benefits-, On IKEA Group <https://www.ikea.com/us/en/this-is-ikea/work-with-us/benefits-pub8c6da021> [accessed 15/12/2019].

IKEA Report. (2021). Sustainable- everyday circular climate-positive energy, On IKEA Group <https://www.ikea.com/ca/en/this-is-ikea/sustainableeveryday/circular-climate-positive-energy> [accessed 5/1/2021].

Lin, C., Yang, H. \& Liou, D. (2009). The impact of corporate social responsibility on financial performance: Evidence from business in Taiwan. Technology in Society, 31(1), 56-63.

Maon, F., Lindgreen, A. \& Swaen, V. (2007). Corporate social responsibility at IKEA: commitment and communication. Research Memorandum, available at: www.academia.edu [accessed 15/12/2020]

Maon, F., Lindgreen, A. \& Swaen, V. (2015). IKEA's road to corporate social responsibility. published by: European Retail Digest, available at: www.researchgate.net [accessed 10/12/2020].

Orlitzky, M. \& Benjamin, J. (2001). Corporate social performance and firm risk: a meta-analytic review. Business\& Society, 40(4), 369- 396.

Pivato, S., Misani, N., \& Tencati, A. (2008). The impact of corporate social responsibility on consumer trust: The case of organic food. Business Ethics A European Review, 17(1), 3-12.

Singh, P., Sethuraman, K., \& Lam, J. (2017). Impact of corporate social responsibility dimensions on firm value: some evidence from Hong Kong and China. Sustainability, 9(9), 1532.

Statistics. (2019). Facts and figures of Inter IKEA Group worldwide from 2009 to 2020. <https://about.ikea.com/en/organisation/ikea-facts-and-figures/inter-ikeagroup-fy19-financial-results/> [accessed 3/12/2019]. 
Statistics. (2019). Net income of INGKA Group (IKEA) worldwide from 2009 to $2020 . \quad<$ https://www.statista.com/statistics/241806/gross-income-of-ikeaworldwide/> [accessed 3/12/2019].

Wu, L., Shao, Z., Yang, C. H., Ding, T., \& Zhang, W. (2020). The impact of CSR and financial distress on financial performance-evidence from Chinese listed companies of the manufacturing industry. Sustainability, 12(17), 6799. 